\title{
Biogeographical and Paleobiogeographical Problems in Stenasellids (Crustacea Isopoda Asellota of Underground Waters)
}

\author{
Guy J. Magniez (*)
}

\begin{abstract}
SUMMARY
Considering their systematic isolation among present Asellota, their strong burrowing behavior, their aptitude for interstitial life and their wide north-tropical present distribution, the history of Stenasellid Crustaceans seems to be marked by the antiquitiy of their settlements in continental groundwaters (Middle Cretaceous period?) and a long stage of life in phreatic waters on permanently emerged paleotropical continents during the Cenozoic Era. The resemblance between some forms of the Guinean shield and Mexico sets the problem of the anteriority of their continental conquest to South Atlantic drift. The repartition of Mediterranean European forms appears as a consequence of paleogeographical changes on Tertiary Times. The distribution of continental European forms has been marked by Quaternary climatic alterations: severe curtailment of settlements, endemicity in Glacial periods but wide Holocene expansion for the forms adapted to new climatic conditions.
\end{abstract}

Captured in the subterranean river of Padirac (SW France), Stenasellus virei Dollfus, 1897 was first considered as a relict isopod (Viré, 1902). In 1938, however, nine Stenasellus species were known from caves and groundwaters of Spain, France, Italy, Yougoslavia, Hungary, and Bulgaria (Husson, 1957). So, the genus was considered as a characteristic of the Southern European troglobitic fauna. Since 1938, 17 Stenasellids have been discovered in the subterianean waters of Africa, 2 in Southern Asia and some 5 in the New World (fig. 1), and the Stenasellids are considered as an independent family, anciently isolated from all other present Asellota stocks (Arcangeli, 1938; Magniez, 1974-75). This group widely colonizes the underground waters of several North-tropical regions of the world with an accessory settlement in Mediterranean Europe.

Some observations made on St. virei pointed up that free-water biotopes (clayey pools, gours, underground rivers) are accessory biotopes. The own nature of stenasellids is phreatobitic as they are able to live in the interstitial water of coarse alluvium. The more important populations live in alluvial valleys and in the gravels of the bed of some rivers. Furthermore, their burrowing behavior is well developed; in clayey alluvium or eluvium they can dig their nets of galleries, more and more ramified, inside which all their life cycle may occur. The young are able to burrow in clay as soon as they leave the 


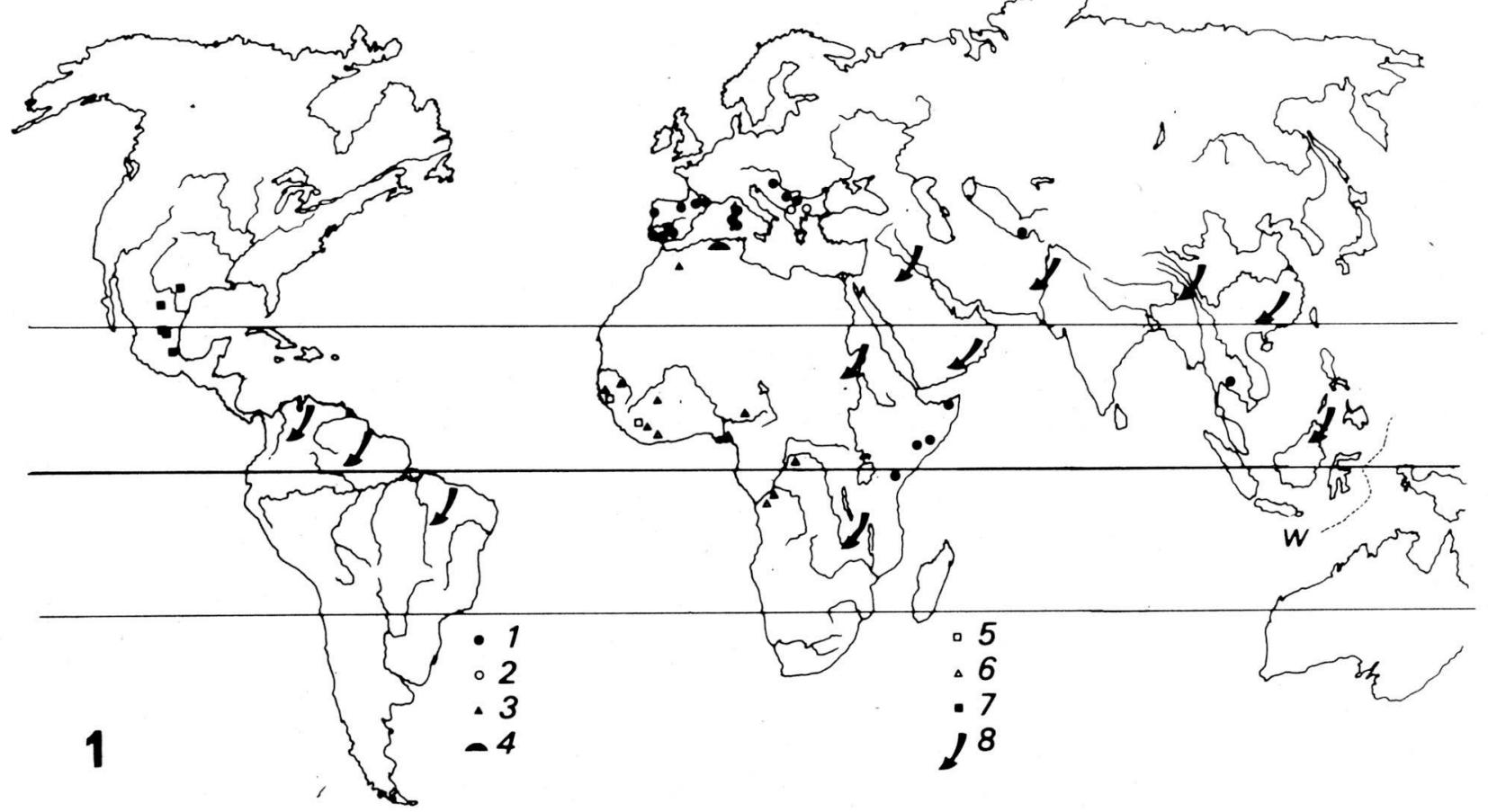

Fig. 1. World repartition of stenasellid isopods. $1=$ Stenasellus stock; $2=$ genus Balkanostenasellus Cvetkov, $1975 ; 3=$ genus Magniezia Lanza, 1966; 4=genus Johannella Monod, 1924; 5 =genus Parastenasellus Magniez, 1966; $6=$ genus MetastenasellusMagniez, 1966; $7=$ American stocks; 8 = arrows pointing out the regions where stenasellids are to be searched for; $W=$ Wallace-Weber line. 
brood pouch. So, we see that the stenasellids are adapted to live in all types of subterranean waters, free water as well as interstitial water. They can also migrate and extend their settlement inside a continuous hydrographic system, and this ecological characteristic is partly responsible for their present dispersal.

\section{SOME PROBLEMS IN THE DISPERSAL OF THE GENUS STENASELLUS}

\section{Stenasellus Virei in Continental France}

In Western Europe, seven endemic Stenasellus species have been found (six in the Iberian Peninsula and one in Mediterranean France). The case of St.virei is quite different: four subspecies of this polytypic species are rather endemic (North Spain, Pyrenees). On the contrary, the last subspecies, St.virei virei, is widely distributed, south as well as north of the Pyrenees (fig. 2). It is the only form that extends widely in the Aquitanian Basin. In this northern part of the area, it is found only in recent interstitial medium: lower terraces of alluvial valleys and underflow of the Garonne and Dordogne rivers and tributaries. The main settlements are always in the lower and middle parts of the valleys, and the underground waters located far from the surface streams are never inhabited by the isopod. We infer that the part of the area of St.v.virei located northwards of the Pyrenees is a zone recently colonized, in Holocene or Postglacial times. Indeed, just after the last glacial sequence (Würm), the rivers have carried and laid down large accumulations of gravels and pebbles which form continuous channels of coarse alluvium, with large interstices, very suitable for the settlement and rapid migrations of the hyporheic fauna (fig. 3). As the periglacial climate had been severe enough, to prevent the stenasellids from living anywhere, but near the Mediterranean or near thermal spring zones, St.virei had been recently an expansive species, being able to extend its settlements over a large area within a period of only some thousands of years. Its expansion is not limited by the present climate, which is propitious, but by the lack of groundwater connections between the GaronneDordogne system and other French hydrographic systems.

\section{Presence of the Virei Stock in Corsica and Sardinia}

A large Stenasellid, St.racovitzai Razzauti, 1925, lives in the karstic and interstitial waters of Corsica and Sardinia. The species is known also in a small karstic area of Tuscany, but this is probably a consequence of a continental connection between Corsica and Tuscany in the early Quaternary, as Tuscany was submerged in Pliocene times. So, St.racovitzai was originally a CorsicaSardinian species. It is strongly related to the species of the Pyrenean zone (virei stock): St.virei, St.buili, St.nobrei, and St.racovitzai have a common origin. Recent geophysical studies point up the fact that the Corsica-Sardinia plate was originally part of a Provence-Catalonia continent, and drifted sou- 


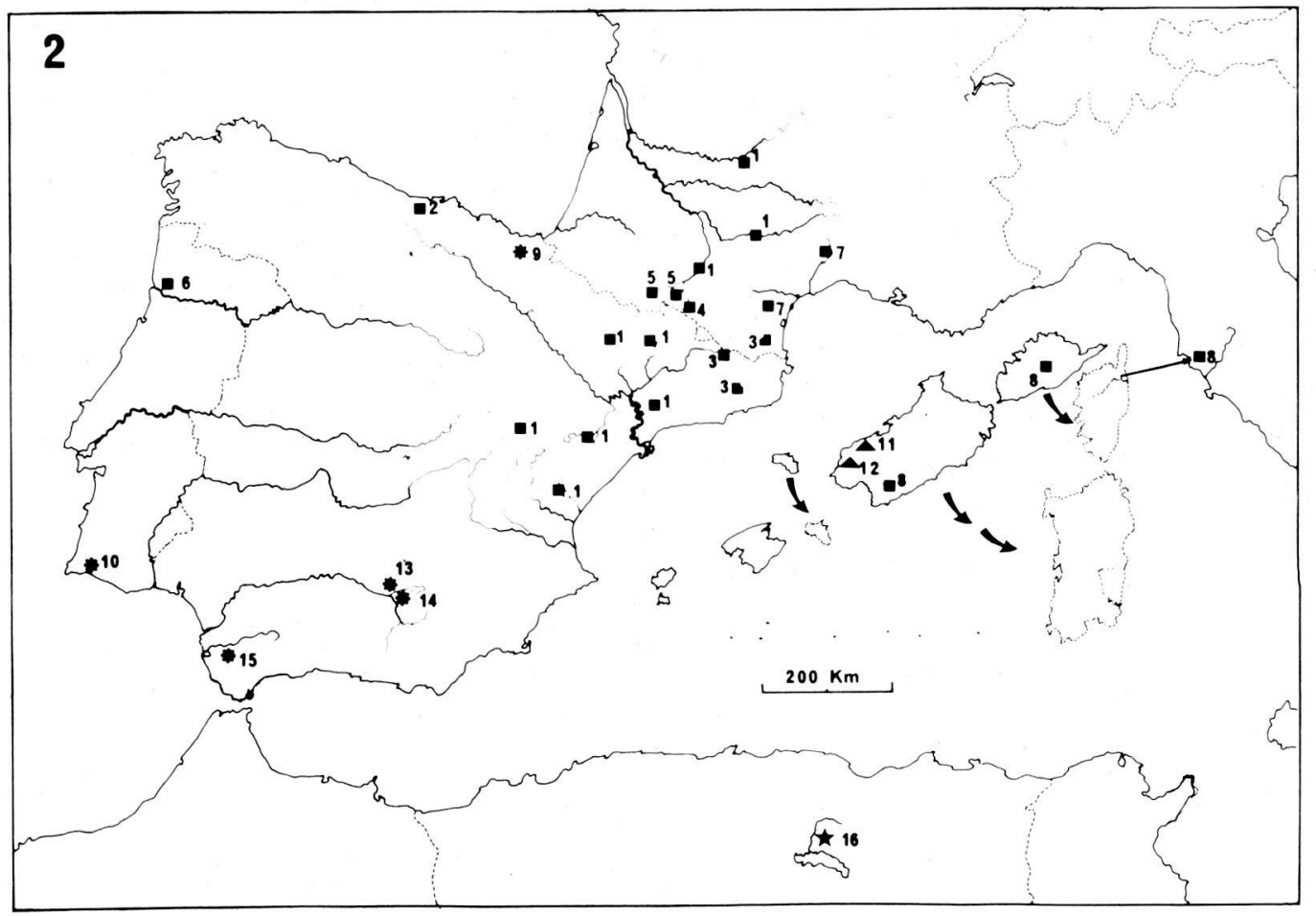

Fig. 2. Repartition of Southwestern Europea!n stenasellids; Corsica, Sardinia and Menorca in Eocene position. Curved arrows point out continental drift, straight arrow points Pleistocene colonization of a point of Tuscany by St.racovitzai. Note the endemicity of all forms, except St.virei virei (1). 1 = Stenasellus virei Dollfus, 1897, subsp. virei or subsp. indet. southeastwards Ebro River; $2=$ St.virei, subsp. buchneri Stammer, 1936; 3 =St.virei, subsp. angelieri Magniez, 1968; 4 =St.virei subsp. boui Magniez, 1968; 5=St.virei, subsp. hussoni, Magniez, 1968; 6 = St.nobrei Braga, 1942; 7 = St.buili Remy, 1949; 8 =St. racovitzai Razzauti, 1925; $9=$ St. breuili Racovitza, 1924; $10=$ St.galhanoae Braga, 1962; $11=$ St.nuragicus Argano, 1968; $12=$ St.assorgiai Argano, 1968; $13=$ St.bragai Magniez, 1976; 14 =St.escolai Magniez, 1976; 15 =St.magniezi Escolà, 1976; 16 = Johannella purpurea Monod, 1924 (African stock). 


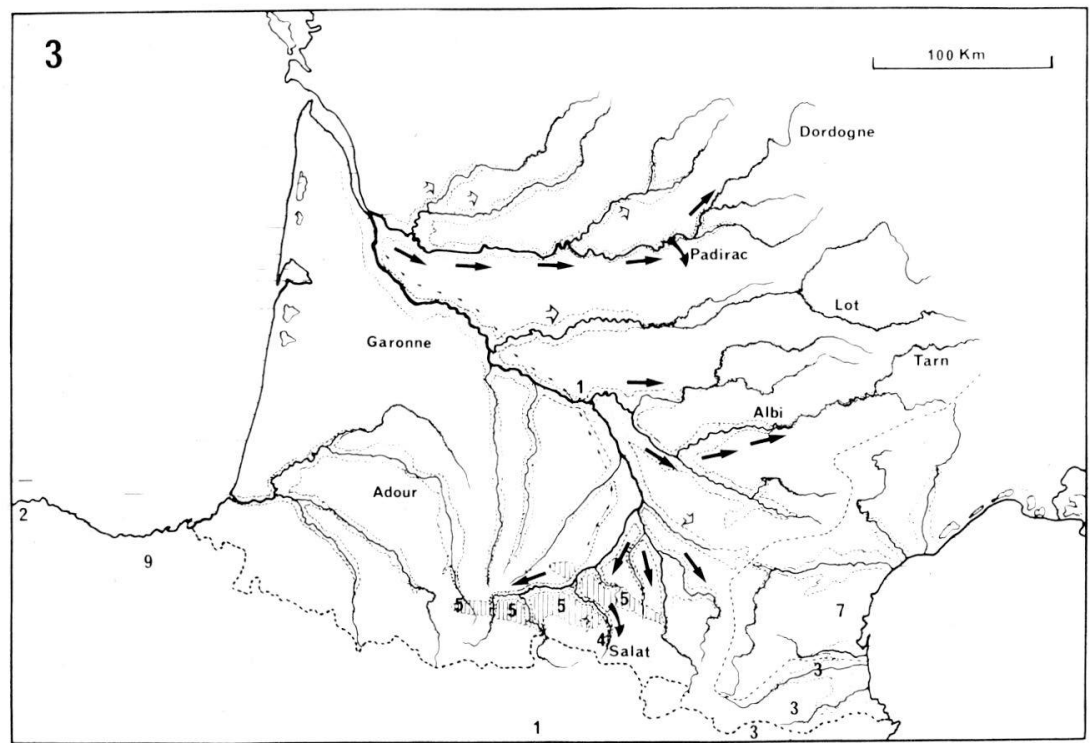

Fig. 3. Colonization of the underground waters of the Aquitanian Basin by Stenasellus virei virei on Holocene times: dotted zones = alluvial valleys with groundwaters; thin arrows $=$ migrations of the fauna under main river; large straight arrows $=$ migrations upwards under the tributaries (black arrows = presence proved by prospections; empty arrows $=$ presence supposed); curved arrows $=$ settling of the karstic system of Padirac; subspeciation and colonization upwards in the underflow of Salat River by St.virei boui; hatched area = north-Pyrenean karstic area of St. virei hussoni; dashed line = limit of area of St.buili; numbers as in fig. 2 .

theastward between the Middle Eocene and the Early Miocene (fig. 2). So, this explains the present dispersal of the virei stock (together in the Pyrenean zone and Corsica-Sardinia, and only there!). Hence, in the Middle Eocene epoch, the stenasellid lines were already a phreatobitic fauna on the Tyrrhenian plate.

\section{General Dispersal of the Genus Stenasellus}

The species of Stenasellus sensu lato (Stenasellus s.s. + Balkanostenasellus Cvetkov, 1975), are known from Southwestern Europe, the Balkan Peninsula, Southeastern and Southwestern Asia and Eastern Africa. Concerning the European stocks, we can state that their areas of distribution always include some continental zones which emerged a long time ago (at least at the beginning of Cretaceous times) - Iberian Meseta for the breuili stock, Tyrrhenian continent for the virei stock, Paleodinarides and Dinarides for the hungaricus and Balkanostenasellus stocks (fig. 4). So, if the Corsica-Sardinia drift indi- 


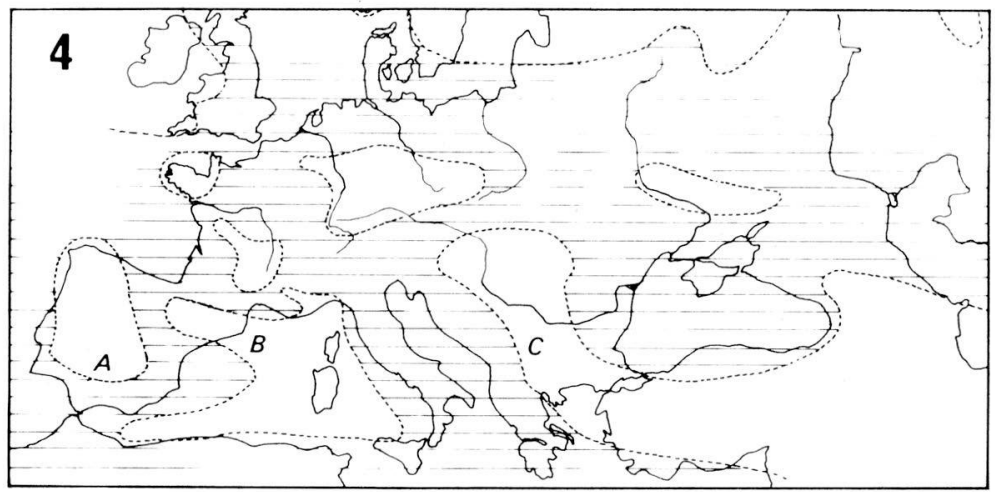

Fig. 4. Paleogeographical map of Europe on Upper Cretaceous, pointing the continental areas of the Mesogean region. Since Lower Cretaceous, these areas are available for colonization by marine ancestors, but we cannot know the date of this colonization. $\mathrm{A}=$ Iberian land (colonized by breuili stock); $\mathrm{B}=$ Tyrrhenian land (colonized by virei stock); $\mathrm{C}=$ Balkan land (colonized by hungaricus and Balkanostenasellus stocks).

cates that continental life was established in the Middle Eocene, then, this life should be more ancient, because the continental medium was available as long ago as early Cretaceous time.

The East-African and South-Asiatic species seem to be morphologically related. However, their three areas (Kenya-Somalia, Turkmenistan, and Cambodia) are so remote from each other that it is untimely to discuss their case. It would be useful to know whether some intermediate populations exist or not, perhaps in the Southern Arabian Peninsula (which was bound to East Africa for a long time), Turkey-Iran region, Central Asia or Southern China. Furthermore, it is not unlikely that the genus Stenasellus was a complex stock, with a common Mesogean ancestor but several independent continental populations.

\section{SOME PROBLEMS IN THE DISPERSAL OF WEST AFRICAN STENASELLIDS}

In Western and Central Africa, three distinct stocks are found - the genus Metastenasellus Magniez, 1966 (six species from the Congolese shield and Gulf of Guinea zone), the genera Parastenasellus Magniez, 1966 (one species) and Magniezia Lanza, 1966 (four species), from the Guinean shield. The species of Magniezia live in underground waters of exorheic basins (Senegal, Gambia, and Sassandra Rivers) as well as in the upper basin of the Niger River, which is an ancient endorheic basin. Recently, I described a new Magniezia (M.gardei, fig. 5) from a Southeastern Moroccan cave (in the upper endorheic basin of the Saoura River). This species is cut off from its congeners 

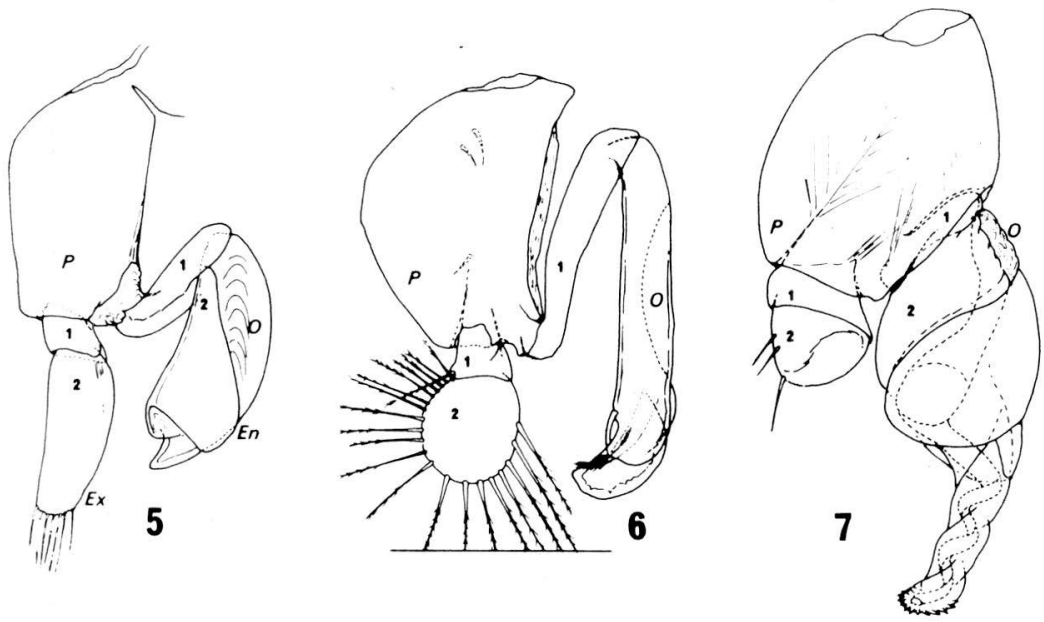

Figs. 5,6,7. $\circ$ 2nd pleopods of the three main African stocks: 5=Magniezia gardei Magniez, 1978, from southern Morocco. Copulatory organ nontwisted. $6=$ Stenasellus kenyensis Magniez, 1974, from Kenya. Copulatory organ slightly twisted. 7=Metastenasellus leleupi (Chappuis, 1951) from Zaire. Copulatory organ strongly twisted. $\mathrm{p}=$ protopodite; En=endopodite; $\mathrm{Ex}=$ exopodite 1 = proximal segment; 2 =distal segment; $\mathrm{O}=$ afferent opening of 2 .En.

by some $2000 \mathrm{~km}$ of arid land (the Western Sahara desert). Since Pliocene ages, the Saharian region has experienced a succession of arid and rainy periods (Faure, 1969; Monod, 1958). During rainy periods, the hydrographic systems became permanent - Oued Saoura coming from the North, Hoggar Rivers from the East, the Upper Niger (not yet captured) from the SouthWest and fed huge freshwater lakes and the phreatic waters developed widely. The present arid period began about 3000 B.P. We can suppose that the Antepleistocene distribution of the genus Magniezia was the entire WestAfrican plate, and the present dispersal is residual. The settlement in eluvial phreatic waters of the West-African craton may be very ancient, as a permanent continental area exists here also and was grazed only by a marine channel (Mediterranean-Gulf of Guinea), on late Cretaceous and Paleocene ages.

\section{THE TRANSATLANTIC DISTRIBUTION OF STENASELLIDS}

Following the discovery of the group in the Western Hemisphere (Cole and Minckley, 1972), some five species have been discovered from Southern Mexico (Argano, 1973) to Southern Texas (Longley, in litt.). In spite of the fact that the males of several species have not been described, the American stocks seem to be well diversified and likely multigeneric. I agree with Cole and Minckley that a certain resemblance exists between Mexistenasellus coa- 
huila from thermal springs of northeast Mexico (fig. 9) and the genus Parastenasellus from the Guinean shield (fig. 8). If it means a relationship with a common continental stock, the continental life of the line must be more ancient than the Cenozoic Era, as the last continental connection between Africa and South America was broken in the Turonian Ages. In this hypothesis, the continental life of African stocks began at least by the early Upper Cretaceous. If some stenasellids are discovered in the future in the phreatic waters of northeast South America (Venezuela-Guiana shield), their study will bring new data for this problem. Furthermore, it will be necessary to explain by what means this groundwater fauna had been able to settle North America, the two American plates having been isolated from each other during the major part of Cenozoic times. Two other hypotheses are possible (fig. 11) - a direct colonization of the North American shield by the same marine stenasellid stocks as in Africa, or that the present American fauna could be a remain of a general preglacial North American settlement; may be in relation with a previous Laurasian settlement (ante Eocene, i.e. prior to the North Atlantic gap).

\section{CONCLUSIONS}

As a consequence of the discovery of numerous north-tropical species, the history of stenasellid isopods appears more complex than former authors thought (Stammer, 1936; Arcangeli, 1938; Chappuis in Racovitza, 1950). The
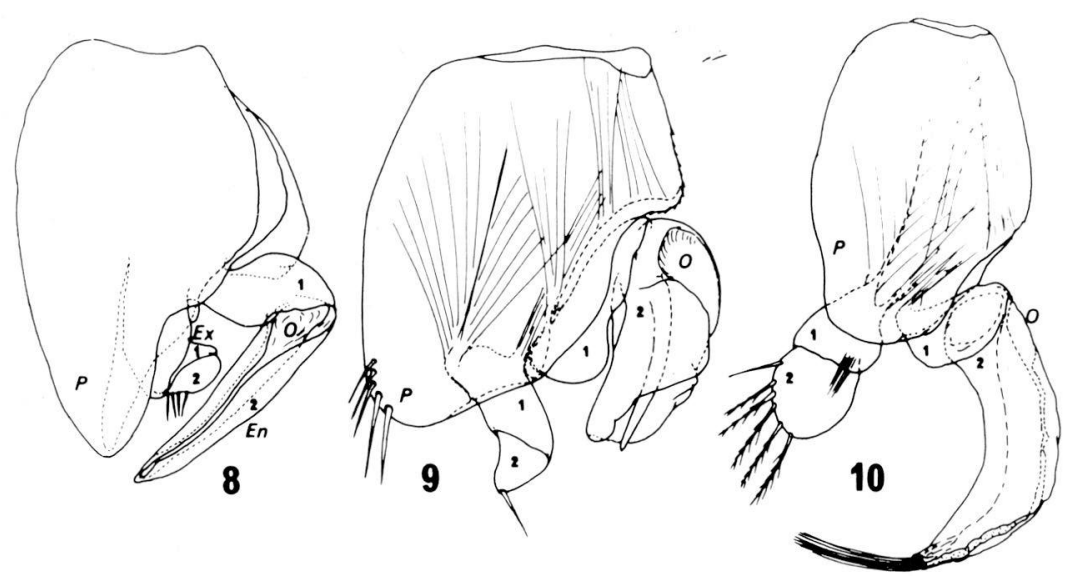

Figs. 8,9,10. or 2nd pleopods of American stocks and African Parastenasellus: $8=$ Parastenasellus chappuisi (Remy, 1938), from Ivory Coast. $9=$ Mexistenasellus coahuila Cole and Minckley, 1972, from northeastern Mexico. 10= Mexistenasellus parzefalli Magniez, 1972, from Central Mexico. A similar organization is visible in P.c., but M.p. is quite different. When the 2 nd $\sigma^{*}$ pleopods of all American species are known, it will appear that the stock is multigeneric. 

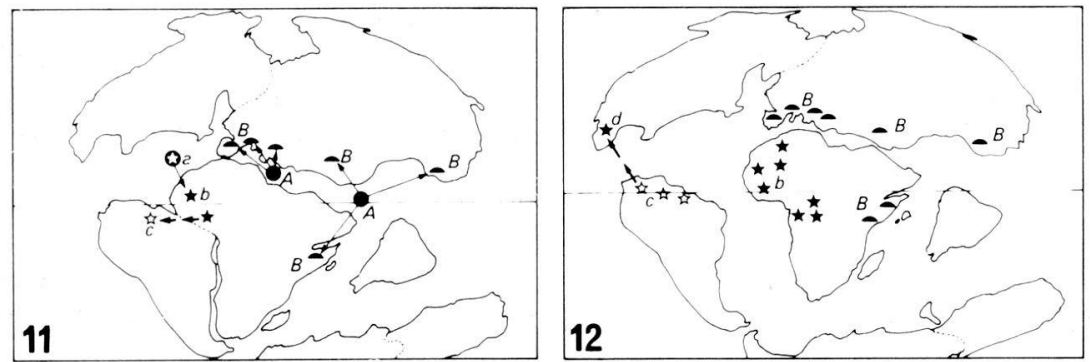

Figs. 11,12. World maps on the beginning (11) and end (12) of Cretaceous times with an hypothesis on the origin of New World stenasellids. a = Mesogean ancestors of the West and Central African stocks; $\mathrm{b}=$ settlement of the Guinean shield and extension; $\mathrm{c}=$ extension to northeast South America; $\mathrm{d}=$ later extension to Southern North America. $\mathrm{A}=$ Mesogean ancestor of the Stenasellus stock; $\mathrm{B}=$ different continental settlements of Stenasellus lines.

marine Mesogean ancestors could have been already interstitial and burrowers in littoral deposits. It is difficult to date their migrations toward continental groundwaters, however, if they are prior to the South American drift, they cannot have occured later than early Upper Cretaceous. This settlement cannot be understood as a passive bringing of marine transgressions, but as an artive conquest upwards by the mean of paleohydrographic systems underflows. Then, a long period of groundwater life could have occurred in the eluvium of paleotropical permanent continental shields. This type of life is always the same for the stocks of wet tropical regions, and their history seems to have been stable. The Mediterranean stocks could have suffered geological aggressions during Cenozoic times - Alpine orogenes, with continental breaking up and drift, marine comings and goings, development of salty basins, etc. ... Then, the Southern European stocks have been affected by Glacial periods, resulting in partial destruction of the stocks(?) endemicity in thermal springs (Lattinger-Penko, 1972), but adaptation to cool conditions for some forms (Magniez, 1974-1975). Finally, in Holocene ages, the latter could have been able to colonize newly suitable hydrographic systems, as in the Aquitanian Basin.

This is a preliminary draft of the history of the group and further investigations and studies are necessary to uncover the details of its different stages.

\section{RÉSUMÉ}

Compte tenu de leur isolement systématique parmi les Asellotes actuels, de leur comportement fouisseur développé, de leur aptitude à la vie interstitielle et de leur vaste répartition mondiale nord-tropicale, l'histoire des Stenasellidae semble marquée par la grande ancienneté de leur installation dans les eaux souterraines continentales (période méso-crétacée?) et par une longue phase de vie dans les eaux phréatiques paiéotropicales des terres émergées en permanence à l'ère tertiaire. La similitude de certaines formes du bouclier guinéen et du Mexique pose le problème 
de l'antériorité de leurs peuplements par rapport à l'ouverture de l'Atlantique Sud. La répartition des formes d'Europe méditerranéenne porte la trace des bouleversements paléogéographiques tertiaires, tandis que leur distribution en Europe continentale a été, de surcroît, troublée par les variations climatiques quaternaires: restrictions des peuplements, endémicité, lors des phases glaciaires, mais large expansion holocène des formes s'étant adaptées aux nouvelles conditions climatiques.

\section{LITERATURE}

ARCANGELI, A. 1938. Stenasellus racovitzai Razzauti, Crostaceo Isopodo acquatico cavernicolo italiano. La famiglia Stenasellidae. Boll. Mus. Zool. Anat. Comp. Torino, 46,1750 .

ARGANO, R. 1973. Mexistenasellus magniezi n.sp., a blind isopod from Veracruz, Mexico (Crustacea). Accad. Naz. Lincei, Roma, 171,97-103.

BÂNARÊSCU, P. 1972. Types of distribution pattern among fresh-water animals. Rev.Roum.Biol., Zool. Bucarest, 17,23-30.

BARR, Th.C., Jr. and J.R. HOLSINGER 1971. Biogeography of Troglobites. Nat. Speleol. Soc. Bull. . U.S.A., 33,115-118.

BOWMAN, Th.E. 1964. Antrolana lira, a new genus and species of troglobitic cirolanid isopod from Madison Cave, Virginia. Int. J. Speleol., 1,229-236, 8 pl.

CHAPPUIS, P.A., et Cl. DELAMARE-DEBOUTTEVILLE 1954. Les Isopodes psammiques de la Méditerranée. Arch. Zool. exper. gén. Fr., 81,103-138.

COLE, G.A. and W.L. MINCKLEY 1972. Stenasellid Isopod Crustaceans in the Western Hemisphere - A new genus and species from Mexico - With a review of other North American freswater Isopod Genera. Proc. Biol. Soc. Washington, 84,313-326, (1971).

CVETKOV, L. 1975. Sur la position systématique des Stenasellinae (Crustacea, Asellota) de Bulgarie. Act. Zool. Bulgar., 1,9-22.

FAURE, H. 1969. Lacs quaternaires du Sahara. Mitt. Internat. Verein. Limnol., Stuttgart, $17,131-146$.

FURON, R. 1957. Le Sahara - Géologie - Ressources minérales - Mise en valeur. Payot, Paris, $300 \mathrm{pp}$.

HOLSINGER, J.R. 1973. Two new species of the subterranean amphipod genus Mexiweckelia (Gammaridae) from Mexico and Texas, with notes on the origin and distribution of the genus. Ass.f.Mexican Caves Studies, Austin, Texas, Bull., 5,1-12.

HOLSINGER, J.R., and G.W. DICKSON 1977. Burrowing as a mean of survival in the troglobitic Amphipod Crustacean Crangonyx antennatus Packard (Crangonyctidae). Hydrobiologia, 54,195-199.

HOLSINGER, J.R., and W.L. MINCKLEY 1971. A new genus and two new species of subterranean Amphipod Crustaceans (Gammaridae) from Northern Mexico. Proc.Biol.Soc. Washington, 37,425-444.

HUGHES, N.F. (ed) 1972. Organisms and continents through time: a symposium. Spec. Pap. Palaeontol., London, 12, VI $+334 \mathrm{pp}$.

HUSSON, R. 1957. A propos de la biologie du Crustacé troglobie aquatique Stenasellus virei Dollfus. Ann.Univ.Sarav.Sc., 6,259-269.

LATTINGER-PENKO, R. 1972. Contribution à la biologie de Stenasellus hungaricus thermalis Mestrov. Crustaceana, Suppl. 3,117-133.

MAGNIEZ, G. 1974-1975. Contribution à la connaissance de la biologie des Stenasellidae (Crustacea Isopoda Asellota des eaux souterraines). Int. J. Speleol., 6,1-80 and 115-171; $7,79-228$.

MAGNIEZ G. 1978. Magniezia gardei n.sp. (Crustacea Isopoda Asellota): un Sténasellide des eaux souterraines du Maroc sud-oriental. Int. J. Speleol., 9,321-329.

MESSANA, G., L. CHELAZZI and B. LANZA 1974. Stenasellus migiurtinicus $\mathrm{sp}$. n., Isopode freatobio della Somalia settentrionale. Monit. Zool. Ital. N.S. Suppl., 5,325-340.

MONOD, Th. 1958. Majâbat al Koubrâ. Contribution à l'étude de l' "Empty Quater" ouestsaharien. Mém. Inst. fr. Afr. noire, Dakar, 52,407 pp.

POULSON, Th. L. and W.B. WHITE 1969. The cave environment. Science, 165, 971-981. 
RACOVITZA, E.G. 1950. Asellides, première série: Stenasellus. Arch. Zool. expér.gén.Fr., 87, $1-94$.

STAMMER, H.J. 1936. Eine neue Höhlenwasserassel aus Spanien, Stenasellus Buchneri und die Verbreitung der Gattung Stenasellus. Zool. Anz. Dtsch., 114-137-141.

TERMIER, H. and TERMIER G. 1974. Tectonique globale et paléogéographie. in Encyclopaedia Universalis, 17,574-579.

VANDEL, A. 1971. Evolution biologique et dérive des continents: une expérience naturelle portant sur cent cinquante millions d'années. C.R.Acad.Sc.Fr., 272,253-256.

VIRÉ, A. 1902. La faune et la flore souterraines de Puits de Padirac (Lot). Bull. Mus. Hist. nat. Paris, 8,601-607. 